\title{
EVAPOTRANSPIRATION ESTIMATION USING SSEBop METHOD WITH SENTINEL - 2 AND LANDSAT-8 DATA SET
}

\author{
D.N. Sharma ${ }^{1, *}$, V. Tare ${ }^{1}$ \\ ${ }^{1}$ Civil Engineering Department, Indian Institute of Technology, Kanpur, India - (devaki, vinod)@iitk.ac.in
}

Commission V, SS: Atmosphere, Ocean, Weather and Climate

KEY WORDS: Evapotranspiration, Sentinel-2, Landsat-8, SSEBop

\begin{abstract}
:
Estimation of evapotranspiration (ET) parameters is essential for understanding crop water requirements and to find out the ground water recharge. In situ data collection procedures are generally adopted to measure the parameters required to find ET. Latest remote sensing technologies accompanied by newly launched satellite datasets can supplement the field data collection and analysis by finding out some of the parameters such as land surface temperature, normalized difference vegetation index (NDVI), albedo, emissivity, etc. The Upper Ganga Canal Command Area (UGC) lying between two rivers Ganga and Yamuna situated between two states, namely Uttarakhand and Uttar Pradesh in North India is selected as the study area for this research work. Operational Simplified Surface Energy Balance (SSEBop) method is used to derive high resolution (10m) ET map for the Upper Ganga Canal Command Area. Sentinel-2 multi spectral images were used to derive land use, land cover (LU/LC) maps, NDVI, albedo, etc. Downscaled Landsat 8 images were used to derive land surface temperature of the command area. Meteorological data retrieved from the Indian Meteorological Department (IMD) was used to calculate reference evapotranspiration. ET map of the study area was generated using the above estimated parameters. Further, validation of the obtained ET values was accomplished by gridded ET data obtained from IMD.
\end{abstract}

\section{INTRODUCTION}

Evapotranspiration is the key component of hydrological cycle. It helps to know about climate change, land use, water budget and irrigation. It transfers large volumes of water and energy, in the form of latent heat) from the soil (evaporation) and vegetation (transpiration) into the atmosphere (Yan et al.,2018). Traditionally, ET from agricultural fields has been estimated by multiplying the weather-based reference ET by crop coefficients $(\mathrm{Kc})$ determined according to the crop type and the crop growth stage.

Estimation of evapotranspiration by remote sensing became popular in recent years since it is less expensive than using ground measurement e.g. eddy covariance and requires less ground data. Several methods on surface energy balance models are available to find ET e.g. S-SEBI, SEBS, SEBAL ,METRIC etc. (Roerink et al., $2000 \mathrm{Su}, 2002$ Bastiaanssen et al., 1998 Allen et al., 2007). Senay et al. (2013) introduced Operational Simplified Surface Energy Balance (SSEBop) approach. to produce a seamless ET across image-scenes using remotely sensed thermal data and model-assimilated weather fields.

With advancement in the field of remote sensing, application of new satellites, such as Sentinel-2 is progressively increasing for providing new possibilities of getting better understanding of the hydrological processes at a higher spatial-temporal resolution. Kyalo 2017 used SEBS method for estimating ET by using Sentinel data with moderate resolution MODIS data for Land surface temperature(LST).

In this paper Sentinel data were used together with higher resolution Landsat 8 data $(100 \mathrm{~m})$ instead of MODIS $(1000 \mathrm{~m})$ for LST to derive actual evapotranspiration of UGC command area by using a new technique "SSEBop method". The main objectives of the study are to

(1) use Sentinel 2 images to produce annual ET for the entire UGC command area for June month of 2018.

(2) Use downscaled Landsat 8 data to find out LST.

(3) Evaluate the performance of Sentinel 2 derived ET using gridded datasets obtained from IMD.

\section{STUDY AREA AND DATA COLLECTION}

The Upper Ganga Canal Command Area (Figure 1) is located between about $26^{\circ} 30^{\prime} \mathrm{N}-30^{\circ} 15^{\prime} \mathrm{N}$ latitude and $77^{\circ} 30^{\prime} \mathrm{E}-81^{\circ} \mathrm{E}$ longitude and has an area of 1000000 hectare. It is covered by Ganga river in north, Yamuna river in South, Lower ganga Canal in east and Haridwar district in west. It is spreaded in two state of india namely Uttarpradesh and Uttrakhand

\footnotetext{
${ }^{*}$ Corresponding Author
} 


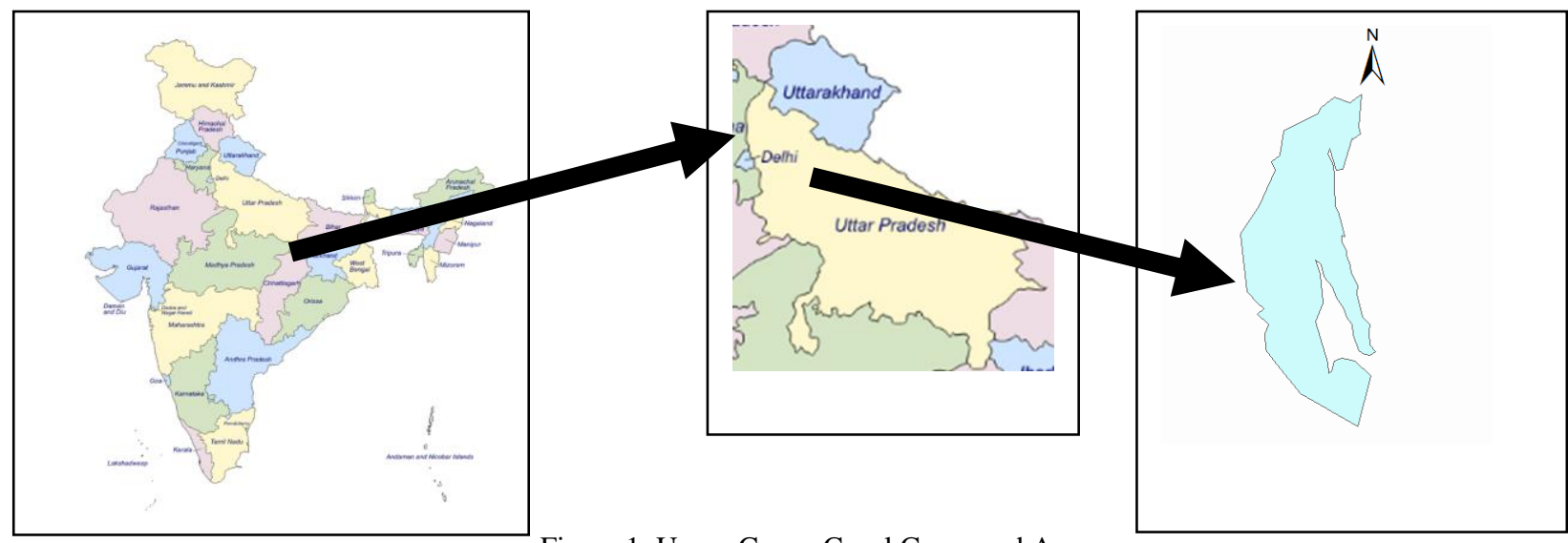

Figure 1. Upper Ganga Canal Command Area

For estimating ET by SSEBop method, data is required mainly Sentinel 2 and Landsat 8 data for image processing. The sources for these satellites data are given in Table 1. Meteorological data is obtained from Indian Meteorological Department (IMD).

\begin{tabular}{|l|c|c|}
\hline $\begin{array}{l}\text { Data/Satellite/Senso } \\
\mathrm{r}\end{array}$ & Parameter & Source \\
\hline Sentinel-2 & $\begin{array}{c}\text { NDVI, } \\
\text { Landsat-8 }\end{array}$ & $\begin{array}{c}\text { https://scihub.coper } \\
\text { nicus.eu }\end{array}$ \\
IMD & LST & $\begin{array}{c}\text { http://earthexplorer. } \\
\text { usgs.gov/ }\end{array}$ \\
& $\begin{array}{c}\text { Meteorological } \\
\text { Data, Gridded ET } \\
\text { data for Validation }\end{array}$ & $\begin{array}{c}\text { http://www.imdpun } \\
\text { e.gov.in }\end{array}$ \\
\hline
\end{tabular}

Table 1. Summary of setellites and Source data

\section{METHODOLOGY}

Sentinel 2 images were downloaded for June month 2018 from ESA with cloud cover less than $60 \%$. Atmospheric correction was done by using Sentinel Sen2Cor. Sentinel 2 images were used to determine NDVI, Fraction of vegetation cover (FVC), Surface emissivity and albedo by following relationship.

$$
N D V I=\frac{\rho_{8}-\rho_{4}}{\rho_{8}+\rho_{4}}
$$

Where $\rho_{8}$ and $\rho_{4}=$ surface reflectance of sentinel-2 bands in NIR and Red spectrum.

FVC and Surface emissivity is derived in following equation (2 \& 3) proposed by Jimenez-Munoz et al. (2009).

$$
F V C=\frac{N D V I-N D V I_{s}}{N D V I_{v}+N D V I_{s}}
$$

Where $N D V I_{s}=$ Bare soil NDVI

$$
N D V I_{v}=\text { NDVI of closed vegetation canopy }
$$

Surface emissivity

$$
\varepsilon=0.004 * \mathrm{FVC}+0.986
$$

Surface Albedo

$$
\begin{aligned}
& \alpha=0.03 \rho_{2}+0.11 \rho_{4}+0.337 \rho_{8}+0.065 \rho_{11}+ \\
& 0.054 \rho_{12}-0.0018(\text { kyalo, } 2017)
\end{aligned}
$$

Where $\rho=$ Surface reflectance of sentinel- 2 bands

Landsat 8 images were downloaded from USGA. Land Surface temperature was obtained by using a modified equation (from Allen et al., 2007). LST data were downscaled from $100 \mathrm{~m}$ to $10 \mathrm{~m}$ spatial resolution.

$$
L S T=\frac{K_{2}}{\ln \left(\frac{\varepsilon^{*} K_{1}}{R_{c}}+1\right)}
$$

where, $\mathrm{K}_{1}$ and $\mathrm{K}_{2}=$ Prelaunch calibration constants $\varepsilon=$ Surface emissivity derived from equation 3 .

$\mathrm{R}_{\mathrm{c}}=$ Corrected thermal radiance using mean values for path radiance, narrow band downward thermal radiation, and narrow band transmissivity of air (Wukelic et al., 1989)

Meteorological data (Tmax, Tmin, wind speed, relative humidity, sunshine hrs, total column water vapor and precipitation) were collected from Indian Meteorological Department (IMD). Reference evapotranspiration $E T_{0}$ and solar radiation $R_{s}$ is derived by Cropwat software developed by Food and Agriculture Organisation (FAO, 1992). Cropwat was also used for getting actual evapotranspiration of kharif season crops in UGC area for validation purpose (Table 2). Based on LST and solar radiation, Net radiation is derived by following relationship.

$$
\begin{aligned}
R_{n}= & (1-\alpha) R_{s}-\mathrm{L} \uparrow+\mathrm{L} \downarrow \\
& \mathrm{L} \uparrow=\varepsilon_{s} * \sigma * T^{4} \\
& \mathrm{~L} \downarrow=\varepsilon_{a} * \sigma * T^{4}
\end{aligned}
$$

Where $R_{s}=$ Solar radiation $\left(\mathrm{W} \mathrm{m}^{-2}\right)$,

$\alpha=$ soil surface albedo

$\mathrm{L} \uparrow=$ Long-wave radiation $\left(\mathrm{W} \mathrm{m}^{-2}\right)$ from the Earth's surface

$\mathrm{L} \downarrow=$ Long-wave radiation $\left(\mathrm{W} \mathrm{m}^{-2}\right)$ from the sky

$\varepsilon_{s} \& \varepsilon_{a}=$ Surfacre emissivity and air emissivity. 
Air emissivity is calculating by following expression proposed by Idso (1981).

$$
\varepsilon_{a}=0.7+5.95 * 10^{-4} * e_{a}^{*} \exp \left(\frac{1500}{T_{a}+273.1}\right)
$$

(9)

$$
\begin{gathered}
e_{a}=\frac{R H}{100} e_{s} \\
e_{s}=0.6107 \exp \left(\frac{17.269}{T_{a}+273.1}\right)
\end{gathered}
$$

where $\mathrm{e}_{\mathrm{a}}=$ Vapor pressure $(\mathrm{kPa})$

RH $=$ Relative humidity $(\%)$ of air

$\mathrm{e}_{\mathrm{s}}=$ Saturated vapor pressure $(\mathrm{kPa})$ at $\mathrm{T}_{\mathrm{a}}$

Finally actual evapotranspiration is calculated by SSEBop method given by Senay et al. (2013).

$$
\begin{gathered}
E T=E T_{f} * \mathrm{k} * E T_{0} \\
E T_{f}=\frac{T_{h}-T_{s}}{d T}=\frac{T_{h}-T_{s}}{T_{h}-T_{c}}
\end{gathered}
$$

where Ts $=$ Satellite-observed land surface temperature of the pixel whose $E T_{f}$ is being evaluated on a given image date.

Th and Tc = Estimated Ts at the idealized "hot/dry" and "cold/wet" reference point.

The difference between Th and Tc is simply the dT.

$$
d T=\frac{R_{n} * r_{a h}}{\rho_{a} * c_{p}}
$$

where $R_{n}=$ Net radiation;

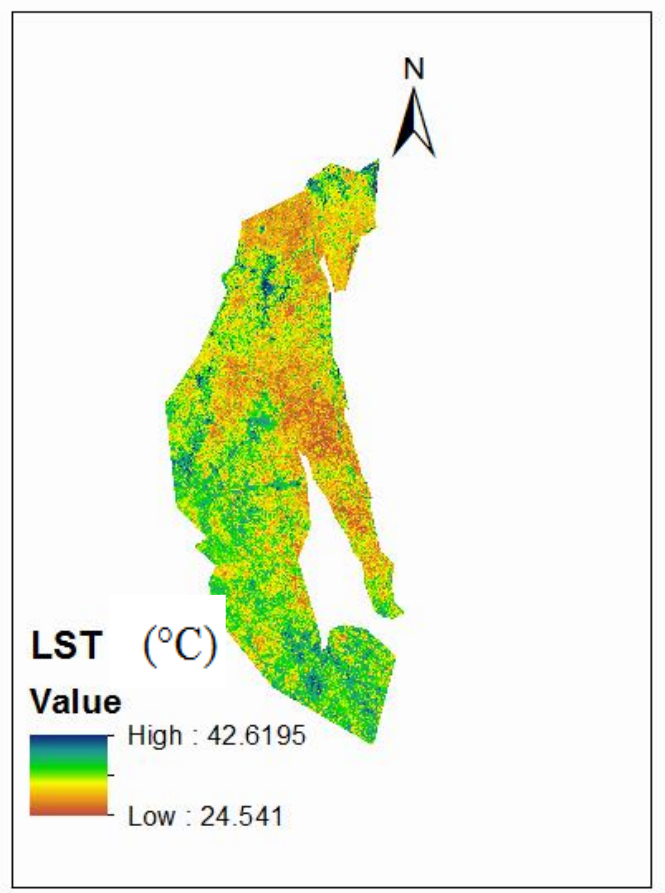

Figure 2. Land Surface Temperature map of UGC

\begin{tabular}{|l|c|}
\hline Crops & ET \\
\hline Maize & 5.74 \\
Paddy & 6.87 \\
Sugarcane & 13.5 \\
Arhar & 4.5 \\
\hline
\end{tabular}

Table 2. ET values estimated by Cropwat

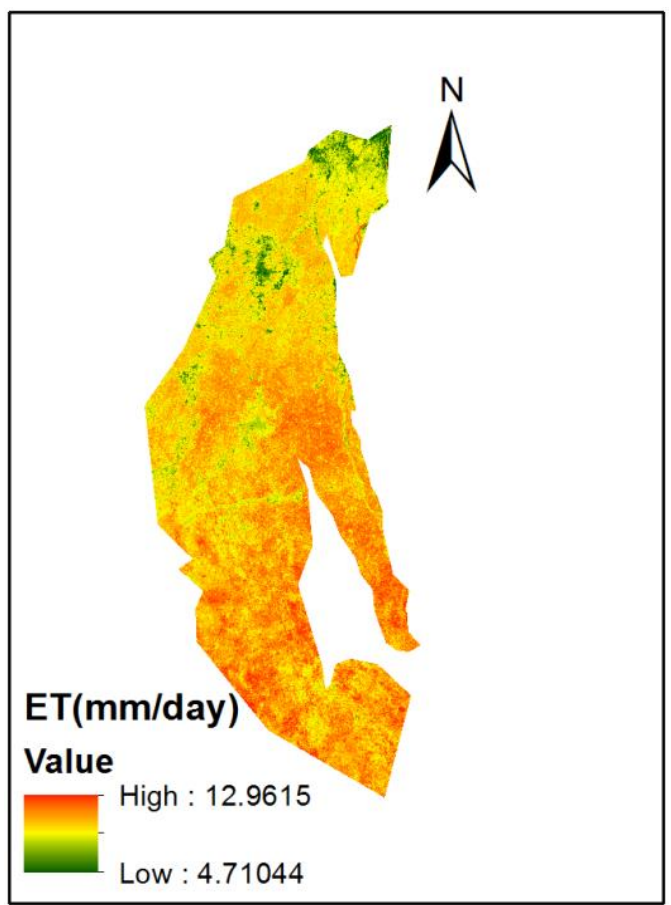

Figure 3. Actual Evapotanspiration map of UGC

$r_{a h}=$ Aerodynamic resistance to heat flow from a hypothetical bare and dry surface, estimated at $110 \mathrm{sm}^{-1}$ (Senay et al., 2013); 
$\rho_{a}=$ Density of air $\left(\mathrm{kgm}^{-3}\right)$, estimated as a function of air pressure and temperature (Allen et al., 1998)

$c_{p}=$ Specific heat of air at constant pressure $\left(1.013 \mathrm{~kJ} \mathrm{~kg}^{-1}{ }^{\circ} \mathrm{C}\right.$ $-1)$.

Hence Actual evapotranspiration can be expressed by following relationship-

$$
E T=\frac{\rho_{a}^{*} c_{p}}{R_{n} * r_{a h}}\left(T_{h}-T_{s}\right) * k * E T_{0}
$$

\section{RESULTS}

To estimate Evapotranspiration of UGC command area, the Sentinel and Landsat images was reprocessed using SSEBop method. SNAP software were used for Image processing. LST was estimated with Landsat image due to its High resolution Thermal infrared band (TIR).. Spatial variation of downscaled Lst is shown in Figure 2. Lower value of LST represent vegetation area and higher value of LST represent barren land. These values varies between $24^{\circ} \mathrm{C}$ to $43^{\circ} \mathrm{C}$. The actual evapotranspiration map of the UGC command area shows the spatial variation of annual ET for June, 2018 (Figure 3). ET is varied widely from low values 4.7 to high values 12.96 . It depends upon mainly climate, land use/land cover, soil moisture availability, vegetation growth and stages, and management practices. Higher value of ET in cropland areas is indicating intensive agricultural practices. higher value represent here kharif crops like sugarcane and paddy.

For validation, ET gridded data obtained from IMD was used. The agreement in ET predicted by two method is considered to be good having an $\mathrm{r}^{2}$ value of 0.71 . Validation was also done with the ET results obtained from Cropwat for different crops of kharif season in UGC area. Paddy, sugarcane, maize and arhar are the main crops of kharif season in this area. ET values for different crops of June month are given in Table 2. Highest ET value of sugarcane in June month is $13.5 \mathrm{~mm} /$ day was estimated by cropwat that is very near to the highest value obtained by SSEBop method.

\section{CONCLUSIONS}

This study was attempted to examine the SSEBop method for mapping spatial variation of actual evapotranspiration over Upper Ganga Canal Command Area. The technique uses Sentinel 2 and Landsat 8 satellite imagery and the SSEBop algorithm to estimate daily ET for June 2018. The actual evapotranspiration (ET ) was estimated using SSEBop were compared with Flux coverance data. Validation showa a good corelation between estimated and measured data. Agriculture terrace shows the highest evapotranspiration (12.96 mm day ) as compared to other land covers. However, the method suggested that in case of scarce ground base data SSEBop technology can serve a quick tool to estimate ET and Instead of Low resolution TIR from Modis satellite data, high resolution TIR from Landsat can also be utilised to estimate ET efficiently.

\section{REFERENCES}

Allen, R. G., Pereira, L. S., Raes, D., and Smith, M.,1998. Crop evapotranspiration: guidelines for computing crop water requirements, in: Irrigation and Drainage Paper 56, FAO, Rome, Italy.

Allen, R. G., Tasumi, M., and Trezza, R.,2007. Satellite-based energy balance for mapping evapotranspiration with internalized calibration (METRIC) - model, J. Irrig. Drain. E.ASCE, 133, 380-394.

Bastiaanssen, W.G.M.; Menenti, M.; Feddes, R.A.; Holtslag, A.A.M.,1998. A remote sensing surface energy balance algorithm for land (SEBAL): 1. Formulation. Journal of Hydrology, v. 212, p. 198-212.

FAO. 1992. CROPWAT, a computer program for irrigation planning and management by M. Smith. FAO Irrigation and Drainage Paper No. 26. Rome.

Idso SB.,1981. A set of equations for full spectrum and 8- to 14-micron and 10.5- to 12.5- micron thermal radiation from cloudless skies. Water Resources Research ;17(2):295e304.

Jiménez-Muñoz, J. C., Sobrino, J. A., Plaza, A., Guanter, L., Moreno, J., \& Martínez, P. (2009). Comparison between fractional vegetation cover retrievals from vegetation indices and spectral mixture analysis: Case study of PROBA/CHRIS data over an agricultural area. Sensors, 9(2), 768-793. https://doi.org/10.3390/s90200768

Roerink, G.J.; Su, Z.; Menenti, M.,2000. S-SEBI: a simple remote sensing algorithm to estimate the surface energy balance. J. Phys. Chem. Earth, v. 25, p. 147-157.

Senay, G. B., Bohms, S., Singh, R. K., Gowda, P. H., Velpuri, N. M., Alemu, H., and Verdin, J. P.,2013. Operational evapotranspiration mapping using remote sensing and weather datasets: a new parameterization for the SSEB approach, J. Am. Water Resour. As., 49, 577-591, doi:10.1111/jawr.12057.

Su, Z.,2002. The Surface Energy Balance System (SEBS) for estimation of turbulent heat fluxes atscales ranging from a point to a continent. J. Hydrol. Earth. Syst. Sci, v. 6, n. 1, p. 85-99.

Thesis :- KYALO, D. K.,2017. Sentinel-2 and MODIS land surface temperature-based evapotranspiration for irrigation efficiency calculations.

Wukelic, G. E., Gibbons, D. E., Martucci, L. M., and Foote, H. P.: Radiometric calibration of Landsat thematic mapper thermal band, Remote Sens. Environ., 28, 339-347, 1989.

Yan, N., Fuyou T., Bingfang W., Weiwei Z., and Mingzhao Y.,2018. Spatiotemporal Analysis of Actual Evapotranspiration and Its Causes in the Hai Basin." Remote Sensing 10, no. 2: 332 . 